\title{
Home ranges and population densities of shrews (Soricidae) inhabiting a spruce plantation in Bavaria, Germany
}

\author{
Thomas M. KOLLARS, Jr
}

\begin{abstract}
Kollars T. M., Jr 1995. Home ranges and population densities of shrews (Soricidae) inhabiting a spruce plantation in Bavaria, Germany. Acta Theriologica 40: 219-222.

The common shrew Sorex araneus Linnaeus, 1758 and pygmy shrew S. minutus Linnaeus, 1766 were live-trapped for 10 months in a spruce plantation. Mean home range sizes were $1058(\mathrm{SD}=381) \mathrm{m}^{2}$ for the common shrew and $2146(\mathrm{SD}=147) \mathrm{m}^{2}$ for the pgymy shrew. The density estimates of $S$. araneus varied from $4 \mathrm{ind} / \mathrm{ha}$ in winter to $26 \mathrm{ind} / \mathrm{ha}$ in summer, and these of $S$. minutus were $2 \mathrm{ind} / \mathrm{ha}$ and $7 \mathrm{ind} / \mathrm{ha}$, respectively. Peak densities for both species occurred during August. It appears that maintaining a viable population of these two shrew species in this spruce plantation requires no special precaution.

Institute for Arthropodology and Parasitology, Georgia Southern University, Landrum Box 8056, Statesboro, GA 30460, USA
\end{abstract}

Key words: Sorex araneus, Sorex minutus, home ranges, densities, population, spruce plantation, Germany

\section{Introduction}

Few studies of the population dynamics of shrews under agricultural conditions have been conducted in Germany (Stein 1961, Bäumler 1981). This capture-mark-recapure study was conducted to determine if home range sizes, population densities, and sex ratios of Sorex araneus Linnaeus, 1758 and S. minutus Linnaeus, 1766 inhabiting a spruce plantation were similar to populations occurring in other habitats.

\section{Methods}

The study area was $128 \mathrm{~m}$ long by $75 \mathrm{~m}$ wide $(0.96 \mathrm{ha})$ and was located in a spruce plantation ( 5 years growth) in the forest of Grafrath, approximately $40 \mathrm{~km}$ west of Munich. The entire plantation was about 25 ha, of which ca $60 \%$ was composed of Picea pungens glauca mixed with Abies grandis and Alnus glutinosa. The other $40 \%$ contained storage buildings and plowed fields. Some of the dominant grasses and herbs were Agropyron repens, Calamagrostis epigejos, Trifolium campestre, $T$. aureum, Taraxacum officinale, Cirsium arvense, Nicia craeca, Hypericum perforatum, Epilobium montanum, and Lupinus sp. The soil was sandy clayous.

The trapping period lasted four days each month, from April 1986 through January 1987, excluding November. Pitfall traps consisting of plastic buckets $(25 \mathrm{~cm}$ diameter $\times 27 \mathrm{~cm}$ height $)$ with 
holes in the bottom for water drainage were placed $7.5 \mathrm{~m}$ apart in a grid 10 by 17 , totaling 170 traps. Traps were checked every 4 hours. Cotton balls and food [1:1 mixture of commercially available Tupaii food (Altromin 8010) with canned dog food] were placed in traps to aid survival of captured shrews (Kollars and Bäumler 1994). Trapped shrews were anesthetized with ether, individually numbered by toe clipping, weighed, sexed, and determined to be juvenile or adult using the criteria of Crowcroft (1956, 1964) and Searle (1985), and released.

A minimum of three captures was considered necessary to estimate home range. Home range and corrected grid size were calculated using the methods of Pernetta (1977) and density estimates using methods of Pucek (1969).

\section{Results and discussion}

There were 134 captures, 68 of $S$. araneus and 25 of $S$. minutus; 41 were recaptures. Eighty-two percent of $S$. araneus and $76 \%$ of S. minutus captured were juveniles.

The mean home range size of juvenile $S$. araneus was $721 \mathrm{~m}^{2}(\mathrm{SD}=161, n=4)$, and for adult female $S$. araneus it was $1395 \mathrm{~m}^{2}(\mathrm{SD}=202, n=2)$. The mean home range size of $S$. minutus was $2146 \mathrm{~m}^{2}(\mathrm{SD}=148, n=2)$. Home ranges of juvenile males and females overlaped intraspecifically only with the opposite sex. Juveniles appeared to have established home ranges by late fall, as found by Pernetta (1977). The mean home range of adult female $S$. araneus (spring) was $48 \%$ larger that that of juveniles (fall). This may indicate that home range sizes of females expanded during the breeding season as Shillito (1963) found that home ranges were smaller in winter than in summer.

Population density, from April through October, was estimated by dividing the corrected grid area by the mean number of vagrants captured each month, and the estimate of the resident population density was added to this number. From

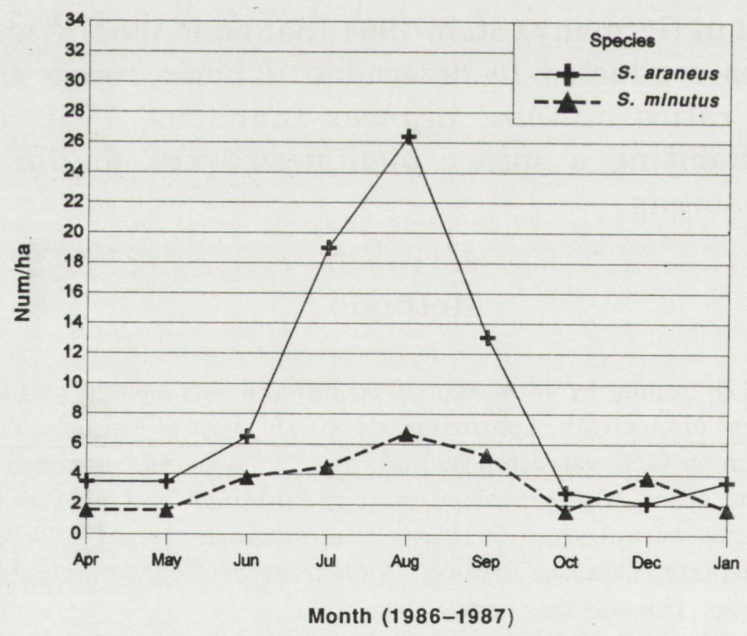

Fig. 1. Population density of Sorex araneus and S. minutus represented as number of individuals per hectare. 
November through January, the population was stable (no births or immigration) because no new unmarked individuals were captured. Therefore, the population density during this period was estimated only by dividing the corrected grid size by the number of captures. The peak population densities (Fig. 1) of $S$. araneus and $S$. minutus occurred during August, with 26 ind/ha and 7 ind/ha respectively. Summer density peaks of other Sorex populations have been shown in many studies (eg Borowski and Dehnel 1952, Pucek 1969, Bäumler 1981).

The density estimates of $S$. araneus, from $4 \mathrm{ind} / \mathrm{ha}$ in winter to $26 \mathrm{ind} / \mathrm{ha}$ in summer, are within the range of other estimates (2 to $71 \mathrm{ind} / \mathrm{ha}$ ) (Crowcroft 1957, Croin-Michielsen 1966, Yalden 1974, Pernetta 1977, Churchfield 1980, 1984). The minimum density of $S$. minutus was $2 \mathrm{ind} / \mathrm{ha}$, and maximum $-7 \mathrm{ind} / \mathrm{ha}$. This is below estimates from other parts of Europe, i.e. $15 \mathrm{ind} / \mathrm{ha}$ in England (Churchfield 1984). But the ratio of $S$. araneus to $S$. minutus found in this study (2.7:1) was similar to those in other agricultural and reclaimed areas in Germany (3.5:1 and 2.2:1, respectively; Heydemann 1960). Ratios of $S$. araneus to $S$. minutus in different habitat types in Germany vary between 125:1 and 1:38 (Löhrl 1938, Schmidt 1973). In a long term study of Soricidae in Białowieża Primeval Forest, Poland, ratios of $S$. araneus to $S$. minutus varied from 3.2:1 to 9.2:1 (Borowski and Dehnel 1952). Although this study was not conducted for an extensive period of time, it would appear that maintaining a viable population of these two shrew species in this spruce plantation requires no special precaution.

Acknowledgements: I thank Professor W. Bäumler for his advice and support. This study was funded in part by Lehrstuhl für Angewandte Zoologie der Ludwig-Maximilian-Universität München, Germany.

\section{References}

Bäumler W. 1981. Die Berbreitung von Mäusen in verschiedenen Waldgebeiten Bayerns. Anzeiger für Schädlingskunde, Pflanzenshutz und Umweltschutz 54: 99-104.

Borowski S. and Dehnel S. 1952. Angaben zur Biologie der Soricidae. Annales Universitatis Mariae Curie-Skłodowska, Sectio C 7: 305-448. [In Polish with English and German summaries]

Churchfield S. 1980. Population dynamics and the seasonal fluctuations in numbers of the common shrew in Britain. Acta Theriologica 25: 415-424.

Churchfield S. 1984. An investigation of the population ecology of syntopic shrews inhabiting water-cress beds. Journal of Zoology, London 204: 229-240.

Croin-Michielsen N. 1966. Intraspecific and interspecific competition in the shrews Sorex araneus and S. minutus L. Archives Néerlandaises de Zoologie 17: 73-174.

Crowcroft P. 1956. On the lifespan of the common shrew. Proceedings of the Zoological Society of London 127: 285-292.

Crowcroft P. 1957. The life of the shrew. Rheinhardt, London: 1-166.

Crowcroft P. 1964. Note on the sexual maturation of shrews Sorex araneus. Acta Theriologica 8: 89-94.

Heydemann B. 1960. Zur Ökologie von Sorex araneus L. und Sorex minutus L. Zeitschrift für Säugetierkunde 25: 24-29.

Kollars T. M., Jr and Bäumler W. 1994. An artificial diet for shrews in the laboratory. Anzeiger für Schädlingskunde, Pflanzenshutz und Umweltschutz 67: 179. 
Löhrl H. 1938. Ökologische und physiologische Studien an einheimischen Muriden und Soriciden. Zeitschrift für Säugetierkunde 13: 114-160.

Mohr E. 1931. Spitzmäuse in Herzogatum Lauenburg. Lauenburg Herzogatum 2: 10.

Pernetta J. C. 1977. Population ecology of British shrews in grassland. Acta Theriologica 22: 279-296.

Pucek Z. 1969. Trap response and estimation of numbers of shrews in removal catches. Acta Theriologica 14: 403-426.

Schmidt E. 1973. Über die mengenmässige Verteilung einiger Spitzmausarten in Ungarn. Acta Theriologica 18: 281-288.

Searle J. B. 1985. Methods for determining the sex of common shrews Sorex araneus. Journal of Zoology, London 206: 279-282.

Shillito J. F. 1963. Observation on the range and movements of a woodland population of the common shrew Sorex araneus. Proceedings of the Zoological Society of London 140: 99-114.

Stein G. H. 1961. Beziehungen zwischen Bestandsdichte und Vermehrung bei der Waldspitsmaus, Sorex araneus, und weiteren Rotzahnsptizmäusen. Zeitschrift für Säugetierkunde 36: 1-64.

Yalden D. W. 1974. Population density in the common shrew, Sorex araneus. Journal of Zoology, London 173: 262-264.

Received 20 June 1994, accepted 22 February 1995. 